\title{
Poglądy respondentów szkół ponadgimnazjalnych dotyczące kształcenia z zakresu podstaw przedsiębiorczości
}

\section{Views of High School Respondents Regarding Education in Entrepreneurship Range}

Streszczenie: Celem artykułu było przedstawienie poglądów wybranych autorów na temat związany z kształceniem młodzieży w zakresie przedmiotu podstawy przedsiębiorczości oraz uzupełnienie tej treści o wyniki przeprowadzonych badań własnych. Badania miały na celu pozyskanie opinii uczniów szkół ponadgimnazjalnych dotyczących przedmiotu oraz poglądów respondentów dotyczących przydatności przedmiotu w ich przyszłości. W badaniach wykorzystano ankietę audytoryjną. Respondenci najczęściej udzielali informacji, że przedmiot podstawy przedsiębiorczości jest raczej przydatny, jednak nie potrafili jednoznacznie stwierdzić, czy przedmiot przygotował ich do przedsiębiorczych działań w przyszłości. Zdecydowana większość respondentów uważała, że liczba godzin w ramach przedmiotu jest wystarczająca. Respondenci określili również najbardziej interesujące ich zagadnienia związane z przedmiotem, m.in. poszukiwanie pracy. Wyników przeprowadzonego badania, ze względu na nieliczną próbę, nie można uogólniać na całą populację osób uczących się w szkołach ponadgimnazjalnych. Mają one za zadanie jedynie zasygnalizować, jakie jest podejście wybranych respondentów do nauczanego przedmiotu. Po przeprowadzeniu badania autorka zauważyła kwestie, o które warto zapytać przy prowadzaniu badań na większej próbie. Są to m.in. plany ucznia oraz czynniki motywujące go do dalszego kształcenia lub podjęcia pracy.

\footnotetext{
Abstract: The aim of this article was to present views of selected authors on education of young people in basics of entrepreneurship and to complement them with the results of own research. The goal of research was to acquire the opinion of high school students about the usefulness of the subject in the future. Random survey was used in the research. Most respondents answered that the subject is rather useful. However, they were not able to explicitly state if this subject prepared them for entrepreneurial activities in the future. Most respondents think that the number of subject hours is sufficient. Respondents identified the most interesting issues of the subject, such as job searching. The results cannot be generalised on the whole population of high school students as the sample group was too small. Their task is to signal the attitude of students towards the subject. After carrying out the research, the author noticed issues worth discussing in the future with a bigger sample. Those include, for example, students' plans for the future and factors that motivate them to continue learning or to work.
} 
Słowa kluczowe: poglądy uczniów; przedsiębiorczość; przewidywania; zainteresowania uczniów

Keywords: entrepreneurship; predictions; students' interests; students' views

Otrzymano: 10 czerwca 2019

Received: 10 June 2019

Zaakceptowano: 12 sierpnia 2019

Accepted: 12 August 2019

\section{Sugerowana cytacja/Suggested citation:}

Dudoń, A. (2019). Poglądy respondentów szkół ponadgimnazjalnych dotyczące kształcenia z zakresu podstaw przedsiębiorczości. Przedsiębiorczość - Edukacja [Entrepreneurship - Education], 15(2), 70-82. doi: 10.24917/20833296.152.5

\section{Wstęp}

W związku z procesami zachodzącymi na rynku globalnym coraz więcej autorów zauważa, że istotne jest, aby przygotować młodych ludzi do wkroczenia na ten rynek. Ważną rolę ma tu odgrywać przedmiot podstawy przedsiębiorczości, który zaznajamia uczniów $z$ różnymi dziedzinami życia gospodarczego - od wyborów konsumentów, postaw przedsiębiorczych, po zasady zakładania i prowadzenia własnej działalności. Autorzy ci podkreślają rangę kształcenia z zakresu przedsiębiorczości na każdym etapie nauki - od edukacji wczesnoszkolnej po edukację na wyższej uczelni (Bigos, 2018: 69; Hajdukiewicz, 2018: 195; Kosała, 2016: 54; Płaziak, Rachwał, 2014: 249; Sadowska, 2016: 149; Wąsik, 2010: 487; Zioło, 2012: 10-11). Oprócz samego przedmiotu podstawy przedsiębiorczości w procesie edukacji postawy przedsiębiorcze mogą być kształtowane przez nauczanie w różnych obszarach kształcenia (Kwaśny, Żur, 2018: 86; Zioło, 2012: 14). Istotnym może okazać się stosowanie przykładów popartych działaniami przedsiębiorczych Polaków i podkreślenie ich wkładu w rozwój nie tylko naukowy, lecz także w rozwój kraju, regionu i świata. Działanie takie może stać się impulsem lub inspiracją dla młodych ludzi do podjęcia podobnych wyzwań (Zioło, 2012: 15).

Głównymi siłami zmiany gospodarczej są edukacja oraz zdobywanie wiedzy (Głodowska, 2017: 107), dlatego w kontekście wzrostu gospodarczego kapitał ludzki odgrywa kluczową rolę (Głodowska, 2018: 223). To, czy młody człowiek wykorzysta przekazywaną wiedzę, czy zrozumie przesłanie z niej płynące, zależy od treści poszczególnych przedmiotów. Ważnym jest, aby odnaleźć ucznia z predyspozycjami do przedsiębiorczości i pomóc mu je kształtować (Zioło, 2012: 15). Przekaz wiedzy pomocnej przy funkcjonowaniu na rynku oraz umiejętności umożliwiające wykorzystanie zdobytej wiedzy mogą przynieść oczekiwane efekty (Maciejewski, 2018: 219).

Aby zainteresować uczniów treścią przedmiotu lub sprecyzować zakres tematów, które warto rozwinąć, należy najpierw zorientować się, czego uczniowie potrzebują i oczekują. Autorka przeprowadziła badania w grupie uczniów, aby sprawdzić, jak kształtują się odpowiedzi dotyczące ich opinii oraz oczekiwań względem przedmiotu. Próba nie była liczna, dlatego nie można uogólniać wniosków na całą populację. Jest to jednak badanie rozpoznawcze, które można rozwinąć w przyszłości. 
Edukacja w zakresie przedsiębiorczości

Od przedsiębiorczości obecnego młodego pokolenia zależy przyszły rozwój kraju. Ważnym elementem procesu wzrostu jest przedsiębiorczość (Premand i in., 2016: 311), a od czasów rewolucji przemysłowej za najbardziej przedsiębiorcze pokolenie uznaje się młodych ludzi XXI w. (Kuratko, 2005: 578). Wskazać można dwa obszary uwarunkowań przedsiębiorczości. Jednym z nich są predyspozycje wrodzone danego przedsiębiorcy do zakładania i prowadzenia biznesu. Drugim rodzajem uwarunkowań są predyspozycje zewnętrzne, czyli czynniki, które zaszczepiają w młodych ludziach ciekawość świata i chęć rozwoju własnej osobowości. Dzięki tym stymulującym czynnikom młodzi poszukują swojej drogi kariery i planują możliwości jej rozwoju (Sadowska, 2016: 150). Przedsiębiorczość nie jest zatem czymś całkowicie niezależnym od decyzji człowieka. Można urodzić się z pewnymi cechami, które mogą okazać się przydatne w budowaniu własnej przedsiębiorczości, ale to właśnie determinacja do działania i chęć rozwoju wpływają na to, czy dana jednostka jest uznawana za przedsiębiorczą czy nie (Sadowska, 2016: 152-153). Ludzie są zmotywowani do działania, jeśli mają poczucie własnej skuteczności (Wilson, Kickul, Marlino, 2007: 389). Tylko wykształceni i odpowiednio przygotowani pracownicy, którzy myślą innowacyjnie w zakresie różnych gałęzi gospodarki oraz potrafią tę myśl wdrożyć do działania, będą kreować w przyszłości innowacyjną gospodarkę. Wzorowanie się na rozwiązaniach z zagranicy i ich dokładne odtwarzanie nie będzie sukcesem, jeśli młodzi ludzie nie będą rozumieli sensu tych działań oraz nie będą dostosowywać ich do warunków panujących w kraju. Dlatego problemy współczesnego rozwoju cywilizacyjnego powinny być poruszane na etapie edukacji (Zioło, 2012: 12-13).

Przedsiębiorczość jest - w kontekście wymagań współczesnego rynku - jedną z ośmiu kompetencji kluczowych w europejskim systemie kształcenia (Płaziak, Rachwał, 2014: 251; Urbaniec, 2016: 77). Oprócz inicjatywności i przedsiębiorczości wśród wspomnianych kompetencji wymienia się również: kompetencje matematyczne i podstawowe kompetencje naukowo-techniczne, świadomość i ekspresję kulturową, porozumiewanie się w języku ojczystym, porozumiewanie się w językach obcych, kompetencje informatyczne, kompetencje społeczne i obywatelskie oraz umiejętność uczenia się (Cichoń, Piotrowska, 2012: 152-153). Nauczanie w zakresie przedsiębiorczości polega na pobudzaniu kreatywności młodych ludzi, motywowaniu ich do rozwiązywania problemów, kształtowaniu umiejętności komunikacyjnych przez pracę w grupach. Są to tzw. kompetencje kierownicze, które rozwijane na etapie edukacji szkolnej okażą się przydatne w planowaniu i zarządzaniu firmą w przyszłości (Wąsik, 2010: 488-489). H. Wąsik (2010: 491) upatruje w przyczynie ubóstwa części społeczeństwa braku podstaw edukacji przedsiębiorczości, która skłaniałaby ludzi znajdujących się w trudnej sytuacji do kreatywnego myślenia i podejmowania działań w celu prowadzenia swojego przedsiębiorstwa. Umiejętność dostosowywania się do zmian i odpowiadania na nie staje się wyzwaniem współczesnych czasów (Kosała, 2014: 319). Z. Zioło (2012: 18) stwierdza, że „drogą do sukcesu indywidualnego i społecznego w zakresie kreowania nowoczesnej bazy ekonomicznej gospodarki opartej na wiedzy jest dobrze przemyślane i zorganizowane kształcenie, dokształcanie i doskonalenie zawodowe, które będzie zmierzać do wykreowania człowieka innowacyjnego o odpowiednio wykształconych cechach przedsiębiorczych. Możliwości rozwoju społecznego, gospodarczego, kulturowego oraz kreowanie racjonalnej polityki stwarzają bowiem tylko odpowiednio przygotowani ludzie, rozumiejący współczesne procesy i przyszłe tendencje 
przemian nawiązujące do nowych wyzwań cywilizacji społeczeństwa informacyjnego". K. Wach (2013: 253) zauważa, że wprowadzenie do planu kształcenia przedmiotów związanych z przedsiębiorczością jest istotne, należy przy tym pamiętać, że ważną rolę odgrywają jednak treści kształcenia poruszane w ramach tych przedmiotów.

Cele przedmiotu podstawy przedsiębiorczości to „wyposażenie uczniów w wiedzę i umiejętności z zakresu podstaw ekonomii i funkcjonowania różnego typu instytucji związanych z gospodarką rynkową oraz kształcenie szeroko rozumianej postawy przedsiębiorczości, w tym otwartości i kreatywności w realizowaniu własnej kariery zawodowej” (Tracz, Rachwał, 2008: 325). Życie każdego człowieka składa się z wyborów dotyczących warunków ekonomicznych, dlatego ważne jest, aby na etapie edukacji wytłumaczyć mu wszystkie mechanizmy rządzące rynkiem, które przydadzą mu się w dorosłym życiu (Zioło, 2012: 15). Na etapie kształcenia z przedmiotu podstawy przedsiębiorczości ważne jest stworzenie dobrych warunków, wykorzystywanie różnych metod nauczania (nie tylko korzystanie z podręcznika czy zeszytu, ale również z form audio-wizualnych) (Tracz, Rachwał, 2007: 288). Nieodzownym elementem przekazywania wiedzy staje się nauczanie interaktywne, np. blended-learning, czyli połączenie nauczania online $\mathrm{z}$ tradycyjną formą przekazywania wiedzy (Wach, 2014: 19). Istotnym jest również to, czy nauczyciel przedmiotu cieszy się sympatią uczniów, czy potrafi ich zachęcić do działania oraz czy potrafi rozpoznać i rozwinąć potencjał swoich uczniów (Ziółkowska-Weiss, 2016: 468). R. Ernst-Milerska (2015: 203) skupiła się na temacie bezrobocia omawianym w ramach przedmiotu podstawy przedsiębiorczości. Zwróciła ona uwagę na fakt, że lekcje przedsiębiorczości często skupiają się jedynie na informowaniu o zjawisku bezrobocia, przedstawiają jego skalę i możliwości, z których mogą korzystać bezrobotni. Natomiast pomijane zostają zagadnienia związane $\mathrm{z}$ przeciwdziałaniem powstawaniu bezrobocia, zarówno czynniki społeczne, etyczne, jak i kulturowe (Ernst-Milerska, 2015: 206). Poczmańska i Pierwieniecka (2016: 400) zauważają, że konieczne jest włączenie przedmiotu podstawy przedsiębiorczości do planu szkół zawodowych i techników. Według wspomnianych autorek, uczniowie najlepiej uczą się przedsiębiorczości przez praktyczne zajęcia, podczas których muszą korzystać ze swoich umiejętności w celu rozwiązania postawionych przed nimi problemów.

\section{Wybrane dotychczasowe badania opinii uczniów na temat przedmiotu podstawy przedsiębiorczości}

W niniejszym artykule zostaną zaprezentowane wyniki badań ankietowych przeprowadzonych wśród uczniów szkół ponadgimnazjalnych w powiecie wadowickim, którzy ukończyli już nauczanie z przedmiotu podstaw przedsiębiorczości lub są na etapie nauki. Podobne badania w roku szkolnym 2012/2013 przeprowadziła M. Tracz, która przeprowadziła ankietę wśród 734 uczniów liceów dla młodzieży oraz wywiady wśród nauczycieli przedmiotu podstaw przedsiębiorczości (Tracz, 2015: 392-393). Badania poruszały temat rangi i znaczenia nauczania przedmiotu podstawy przedsiębiorczości w opinii uczniów i nauczycieli przedmiotu (Tracz, 2015: 391). Autorka porównała uzyskane dane z wynikami badań przeprowadzonych w latach 2004-2013 i stwierdziła, że coraz mniej uczniów wykazuje zainteresowanie przedmiotem oraz chęć nauki w zakresie przedsiębiorczości. Tracz zauważyła również, że większe zainteresowanie wykazywali uczniowie techników niż liceów ogólnokształcących. Przyczyną, według niej, może być fakt, że uczniowie liceów 
myślą o dalszym kształceniu, nie przywiązują uwagi do kwestii związanych z zatrudnieniem na rynku, w przeciwieństwie do osób uczących się w technikum, z których część po ukończeniu szkoły nie kontynuuje nauki na studiach, tylko od razu rozpoczyna pracę. Uczniowie wskazywali, że przydatnymi tematami, które porusza się w czasie lekcji, są m.in. sposoby zakładania własnej firmy i tematy związane z rynkiem pracy (Tracz, 2015: 398).

Kolejną autorką, która przeprowadziła podobne badanie, jest K. Ziółkowska-Weiss. Badanie przeprowadzone było w 2013 i 2015 r. w jednym z andrychowskich liceów. W obu etapach udział brały te same osoby. Badanie miało na celu określenie przez uczniów, które zagadnienia nauczane w ramach podstaw przedsiębiorczości będą przydatne $\mathrm{w}$ ich dorosłym życiu, oraz które zagadnienia najbardziej ich interesowały lub interesują (Ziółkowska-Weiss, 2016: 457). W badaniu w 2013 r. udział wzięło 193 respondentów, a w 2015 r. - 193 respondentów. W kwestionariuszu ankiety zawarto 10 pytań, w tym 8 ze skalą Likerta (Ziółkowska-Weiss, 2016: 459). Z wyników badań wykonanych przez wspomnianą autorkę wynikało, że po dwóch latach nauki ponad dwa razy więcej uczniów uważało wprowadzenie przedmiotu dotyczącego przedsiębiorczości do szkół za słuszną decyzję. Podobnie sytuacja wyglądała z opinią dotyczącą przydatności przedmiotu w życiu dorosłym. Ponad dwa razy więcej uczniów w 2015 r. udzieliło odpowiedzi, że przedmiot przygotuje ich do dalszego życia na rynku, podczas gdy w 2013 r. takiej odpowiedzi udzieliło zaledwie 20,7\% respondentów. Wymieniając różnicę pomiędzy opiniami respondentów w 2013 i 2015 r., Ziółkowska-Weiss zauważyła, że stosunek respondentów do ocenianego przedmiotu zmienił się, a odpowiedzi w 2015 r. zdecydowanie różnią się od tych, które udzielane były w 2013 r. (Ziółkowska-Weiss, 2016: 467-468).

\section{Cel i metody badań}

Celem badań było wskazanie opinii uczniów szkół ponadgimnazjalnych na temat przedmiotu podstawy przedsiębiorczości. Do badań wykorzystano formularz ankiety, który zawierał 19 pytań, przy czym w wypadku 3 pytań uczniowie mieli możliwość rozwinąć swoją odpowiedź. Pytanie trzecie zawierało tabelę z zagadnieniami ujętymi w podstawie programowej dla przedmiotu podstawy przedsiębiorczości, uczniowie mieli możliwość wielokrotnego wyboru treści/zagadnień, które były poruszane na zajęciach, zdaniem respondenta jest interesujące, interesuje respondenta najbardziej oraz interesuje respondenta najmniej. Pozostałe pytania odnosiły się do opinii respondenta dotyczących przedmiotu oraz zagadnień związanych z metryczką.

W badaniu udział wzięło 74 respondentów. Po analizie ankiet okazało się, że ze względu na brak kompletnie uzupełnionych ankiet, dwie z nich musiały zostać odrzucone. Do analizy zakwalifikowano 72 ankiety. Zastosowaną techniką badawczą była ankieta audytoryjna, przeprowadzona $\mathrm{w}$ powiecie wadowickim. Badania przeprowadzano $\mathrm{w}$ okresie marzec-kwiecień 2019 r. Ze względu na nieliczną próbę na wykresach przedstawiona została liczba wskazań danych odpowiedzi zamiast ich udziału procentowego.

Przy dylemacie postawienia bądź niepostawienia hipotezy zasugerowano się informacją, że nie zachodzi konieczność formułowania hipotez roboczych, jeżeli jedynie opisuje się badane fakty lub zjawiska (Łobocki, 1984: 75; Jeszka, 2013: 37). Badania mają charakter diagnostyczny i opisowy, a artykuł nie zmierza do tworzenia uogólnień, praw i twierdzeń, dlatego autorka nie sformułowała hipotez badawczych, lecz wyszczególniła następujące problemy badawcze: opinia uczniów w kwestii liczby godzin przedmiotu 
tygodniowo; opinia uczniów dotycząca przydatności treści nauczanych w ramach przedmiotu w przyszłości; zagadnienia najczęściej i najrzadziej poruszane na zajęciach; zagadnienia najbardziej i najmniej interesujące respondentów; przygotowanie respondentów do podejmowania przedsiębiorczych działań w przyszłości oraz przydatność przedmiotu podstawy przedsiębiorczości w opinii respondentów, których rodzice prowadzą lub nie prowadzą działalności gospodarczej.

Uczniowie biorący udział w badaniu uczęszczali do drugiej (46 wskazań), trzeciej (15 wskazań) i czwartej (11 wskazań) klasy szkoły ponadgimnazjalnej, było to 29 uczniów liceum oraz 43 uczniów technikum.

Najwięcej ankietowanych stanowiły kobiety w wieku 17-18 lat (39 wskazań), następnie w wieku 19-20 (15 wskazań). W badaniu udział wzięło 10 mężczyzn w wieku 17-18 lat oraz 7 mężczyzn w wieku 19-20 lat. Najmniejszą grupę stanowiły osoby w wieku powyżej 22 lat - był to jeden mężczyzna. W badaniu nie uczestniczyły osoby w wieku 15-16 oraz 20-21 lat. Prawie połowa respondentów zadeklarowała zamieszkanie na wsi (47 wskazań, w tym 39 kobiet i 8 mężczyzn). Zamieszkanie w mieście zadeklarowało 15 kobiet oraz 10 mężczyzn.

Na pytanie dotyczące częstotliwości odbywanych lekcji 42 respondentów wskazało, że przedmiot odbywał się przez jedną godzinę w tygodniu, pozostałych trzydziestu respondentów zaznaczyło dwie godziny przedmiotu tygodniowo.

Ponad połowa respondentów (46 osób) uznała, że liczba godzin z podstaw przedsiębiorczości jest wystarczająca (rycina 1). Czterech uczniów uznało, że powinno być mniej godzin przedmiotu tygodniowo. Proponowali oni, aby zmniejszyć wymiar godzin do jednej tygodniowo lub w ogóle zrezygnować z tego przedmiotu. Dwóch respondentów określiło, że powinno być więcej godzin podstaw przedsiębiorczości. Jedna osoba zaproponowała zwiększenie tygodniowego wymiaru godzin do trzech. Reszta respondentów

Rycina 1. Opinie uczniów dotyczące liczby godzin przedmiotu podstawy przedsiębiorczości

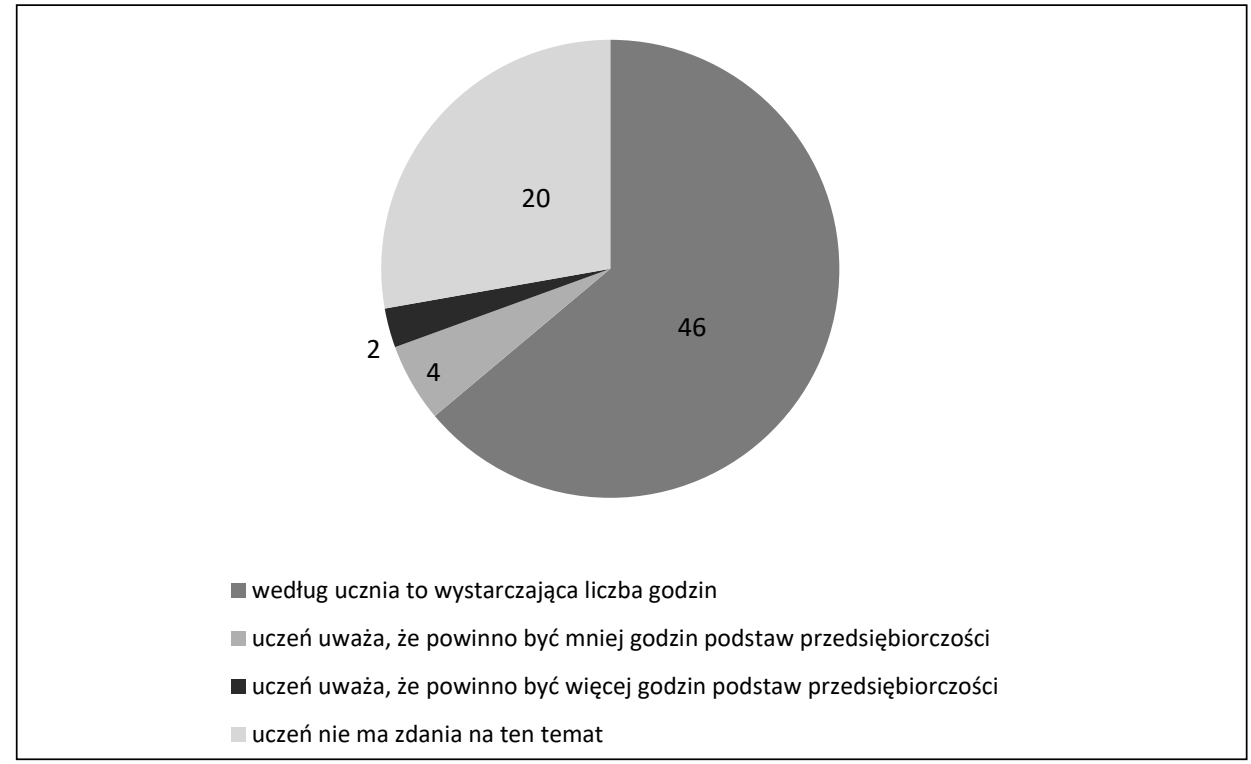

Źródło: opracowanie własne na podstawie badań własnych 
(20 osób) nie miała zdania na ten temat. Z informacji uzyskanych $\mathrm{z}$ ankiet wynikało, że uczniowie liceum odbywali dwie lekcje przedsiębiorczości w tygodniu przez jeden rok, a uczniowie technikum - jedną lekcję tygodniowo przez dwa lata.

Znaczna większość respondentów (68) udzieliła odpowiedzi, że średnia ocen z kartkówek i sprawdzianów była podstawą do wystawienia oceny końcowej, 4 respondentów dodało, że oprócz kartkówek i sprawdzianów oceniany był również projekt założenia własnego biznesu i opracowanie w jego ramach biznesplanu.

Trzech respondentów, uczęszczających do szkoły średniej, pracuje zawodowo. Żaden z respondentów nie prowadzi własnej działalności, 35 respondentów zamierza podjąć dalszą naukę po zakończeniu szkoły. Ponad połowa respondentów (49) zamierza kontynuować naukę na studiach, jeden respondent w szkole policealnej (najczęściej badani wykazywali chęć kształcenia się na kierunkach: dietetyka, kosmetologia, psychologia; 6 respondentów udzieliło odpowiedzi, że zamierzają podjąć naukę w Akademii Wychowania Fizycznego). Dwunastu respondentów stwierdziło, że nie zamierzają podejmować dalszej nauki, a pozostali nie potrafili jednoznacznie określić swoich planów.

Większość uczniów (35 wskazań) zamierza podjąć dalszą naukę po zakończeniu szkoły (rycina 2). W tej grupie 25 osób stwierdziło, że zamierza podjąć pracę po szkole, 8 określiło, że nie zdecydowało jeszcze o podjęciu pracy, a 2 osoby zdecydowanie stwierdziły, że na pewno nie zamierzają podjąć pracę po szkole. Można przypuszczać, że osoby te zamierzają łączyć studia z pracą dorywczą lub podjąć pracę i studia zaoczne. Część uczniów (25) nie wie, czy zamierza podjąć naukę po szkole. W tej grupie nikt nie zaznaczył odpowiedzi, że nie zamierza podejmować pracy po szkole. Mogą to być osoby, które są zdecydowane podjąć pracę, a kwestia związana z możliwością dalszej nauki z pewnością będzie przez nie rozwiązywana później i dostosowywana do ich możliwości, np. finansowych. Wśród uczniów, którzy zdecydowanie stwierdzili, że nie zamierzają

Rycina 2. Deklaracja podjęcia dalszej nauki lub pracy po ukończeniu szkoły

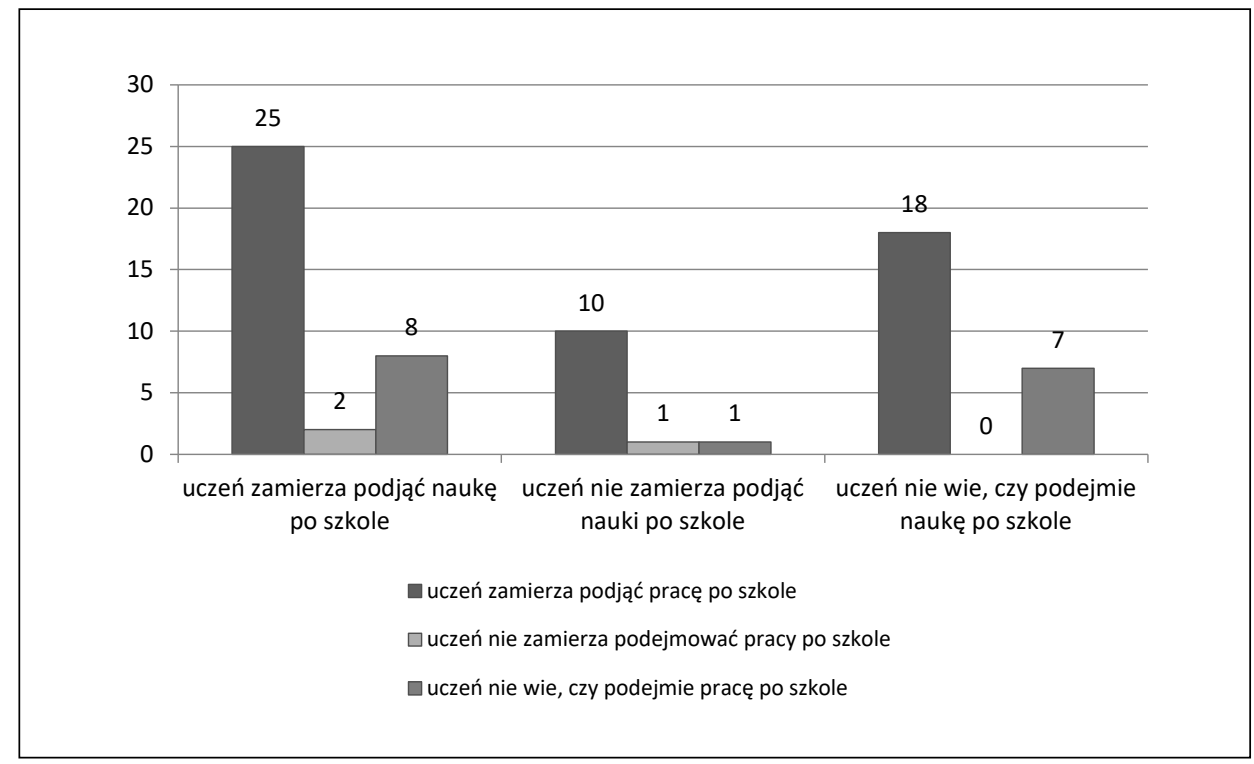

Źródło: opracowanie własne na podstawie badań własnych 
podejmować nauki, 10 respondentów określiło, że zamierza podjąć pracę, niezdecydowanych lub zdecydowanie niechcących podjąć pracy było po jednym respondencie. Autorka badań uważa, że przy badaniach na większej populacji warto zapytać precyzyjniej uczniów o ich plany. Zwłaszcza dotyczące trybu studiów, które chcieliby podjąć, oraz czy zamierzają pracować na pełny etat, czy też rozważają inne formy zatrudnienia. Przydatne mogłoby być również pytanie o to, jakie są motywacje dotyczące podjęcia lub nie pracy bądź dalszej nauki.

W celu określenia różnorodności i atrakcyjności prowadzonych zajęć zapytano uczniów o to, czy w ramach zajęć odbywały się dodatkowe ciekawe wydarzenia.

Tabela 1. Dodatkowe wydarzenia odbywające się w ramach zajęć (liczba wskazań)

\begin{tabular}{|l|c|c|c|}
\hline \multicolumn{1}{|c|}{ Czy w ramach przedmiotu: } & Tak & Nie & Nie wiem \\
\hline $\begin{array}{l}\text { odbywały się wycieczki do lokalnych } \\
\text { przedsiębiorstw? }\end{array}$ & 16 & 52 & 4 \\
\hline $\begin{array}{l}\text { odbywały się spotkania/pogadanki } \\
\text { z przedsiębiorcami? }\end{array}$ & 56 & 14 & 2 \\
\hline $\begin{array}{l}\text { odbywały się przygotowania do wzięcia } \\
\text { udziału w projektach związanych } \\
\text { z przedsiębiorczością? }\end{array}$ & 20 & 43 & 9 \\
\hline $\begin{array}{l}\text { uczniowie byli zachęcani do prezentowania } \\
\text { swoich pomysłów związanych } \\
\text { z przedsiębiorczością? }\end{array}$ & 28 & 29 & 15 \\
\hline $\begin{array}{l}\text { odbywały się ciekawe multimedialne } \\
\text { prezentacje tematów? }\end{array}$ & 32 & 31 & 9 \\
\hline $\begin{array}{l}\text { odbywały się inne ciekawe wydarzenia } \\
\text { niewymienione wyżej? }\end{array}$ & 11 & 42 & 19 \\
\hline
\end{tabular}

Źródło: opracowanie własne na podstawie badań własnych

Według opinii respondentów (tabela 1), w ramach zajęć odbywały się inne ciekawe wydarzenia, które uatrakcyjniały lekcje. Zauważyć można, że w każdej z zaproponowanych atrakcji znalazły się zarówno wskazania odbywania, jak i nieodbywania się tych wydarzeń. Wpływ na wyniki z pewnością miał fakt, że uczniowie nie byli kolegami z jednej klasy, co pokazuje, że prawdopodobnie wydarzenia te miały miejsce z inicjatywy konkretnych nauczycieli przedmiotu. Jest to unaocznienie wspomnianej wcześniej teorii, w której zauważa się, jak istotne jest zaangażowanie nauczyciela w procesie kształcenia młodzieży. Uczniowie, którzy zaznaczyli odpowiedź, że w ramach przedmiotu odbywały się inne ciekawe wydarzenia, wymieniali: spotkanie z coachem oraz tydzień przedsiębiorczości.

Tylko 9 respondentów zdecydowanie stwierdziło, że przedmiot podstawy przedsiębiorczości nie przyda im się w przyszłości (rycina 3). Pozostali stwierdzili, że będzie przydatny (30 wskazań) lub że jeszcze nie wiedzą lub trudno im stwierdzić, czy będzie przydatny (33 wskazania). Można przypuszczać, że przedmiot nie zainteresował 9 respondentów i nie zwrócili oni uwagi, że porusza on kwestie, które w przyszłości na pewno będą ich dotyczyły, np. poszukiwanie pracy, prowadzenie firmy, rozliczanie się z urzędem skarbowym. Prawdopodobnie będą oni w przyszłości zmuszeni do nadrobienia zaległości w kwestiach poruszanych na zajęciach.

Ankietowani mieli też określić, czy zagadnienia poruszane na zajęciach przygotowały ich do podejmowania przedsiębiorczych działań w przyszłości. W skali odpowiedzi: 
Rycina 3. Opinia uczniów w kwestii przydatności przedmiotu podstawy przedsiębiorczości w przyszłości

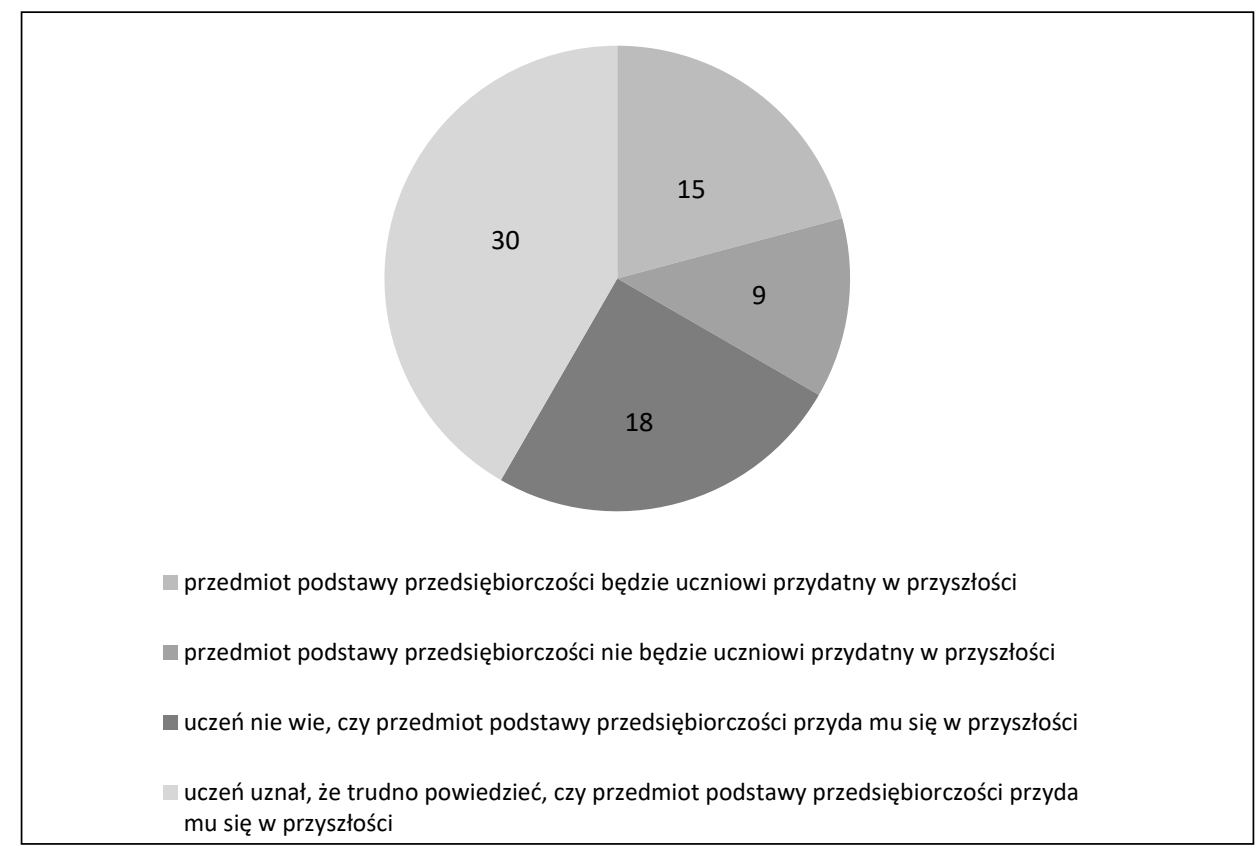

Źródło: opracowanie własne na podstawie badań własnych

„zdecydowanie mnie przygotował”, „raczej mnie przygotował”, „trudno powiedzieć”, „nie przygotował mnie wystarczająco” oraz „w ogóle mnie nie przygotował” uczniowie udzielali odpowiedzi, że przedmiot podstawy przedsiębiorczości raczej przygotował ich do: ubiegania się o pracę (umiejętności przygotowania dokumentów aplikacyjnych, umiejętności komunikacyjne, autoprezentacja), planowania budżetu domowego, planowania rozpoczęcia własnej działalności (tworzenie biznesplanu, analiza SWOT itp.), założenia własnej firmy (kwestie formalno-prawne związane z założeniem działalności), rozliczania się z urzędem skarbowym (wypełnianie formularza PIT i inne). Uczniowie określili, że trudno powiedzieć, czy przedmiot przygotował ich do: przewidywania zjawisk występujących na rynku (umiejętności rozpoznania i dostosowania się do zmian, trendów i kierunku rozwoju rynku), podejmowania decyzji związanymi z oszczędnościami (lokaty, obliczanie odsetek). W odpowiedziach ankietowanych nie znalazła się nawet jedna odpowiedź, że przedmiot w konkretnym zagadnieniu przygotował ucznia zdecydowanie, niewystarczająco czy w ogóle.

Na podstawie ryciny 4 można zauważyć, że rodzice zdecydowanej większości ankietowanej młodzieży nie prowadzą własnej działalności. Oczywiście należy pamiętać, że próbka nie jest reprezentatywna. Autorka przypuszcza, że w przyszłości można byłoby rozwinąć te badania na większą skalę i przeprowadzić ankietę wśród uczniów, których rodzice prowadzą własną działalność, oraz tych, których rodzice nie prowadzą własnej działalności. Być może dałoby się zauważyć jakąś różnicę w ich podejściu do nauczanego przedmiotu. 
Rycina 4. Miejsce zamieszkania i prowadzenie własnej działalności przez rodziców ucznia

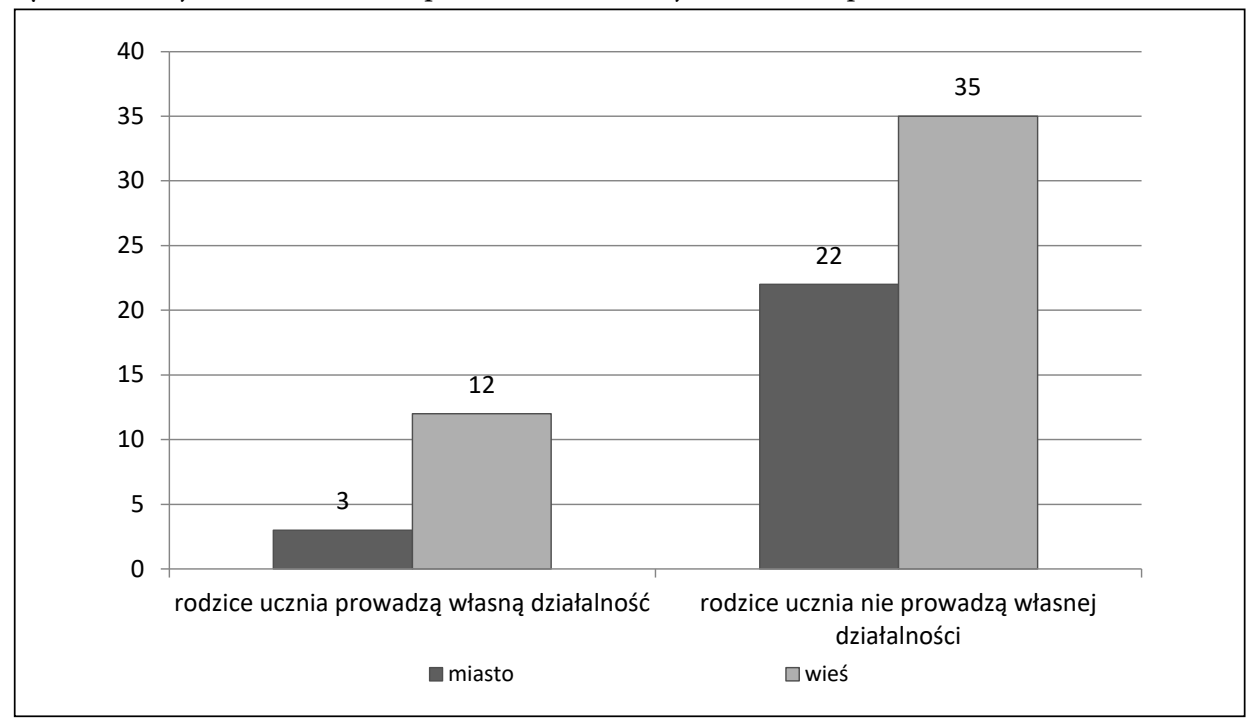

Źródło: opracowanie własne na podstawie badań własnych

Rycina 5. Przydatność w przyszłości nauczanego przedmiotu w opinii uczniów, których rodzice prowadzą lub nie prowadzą własnej działalności

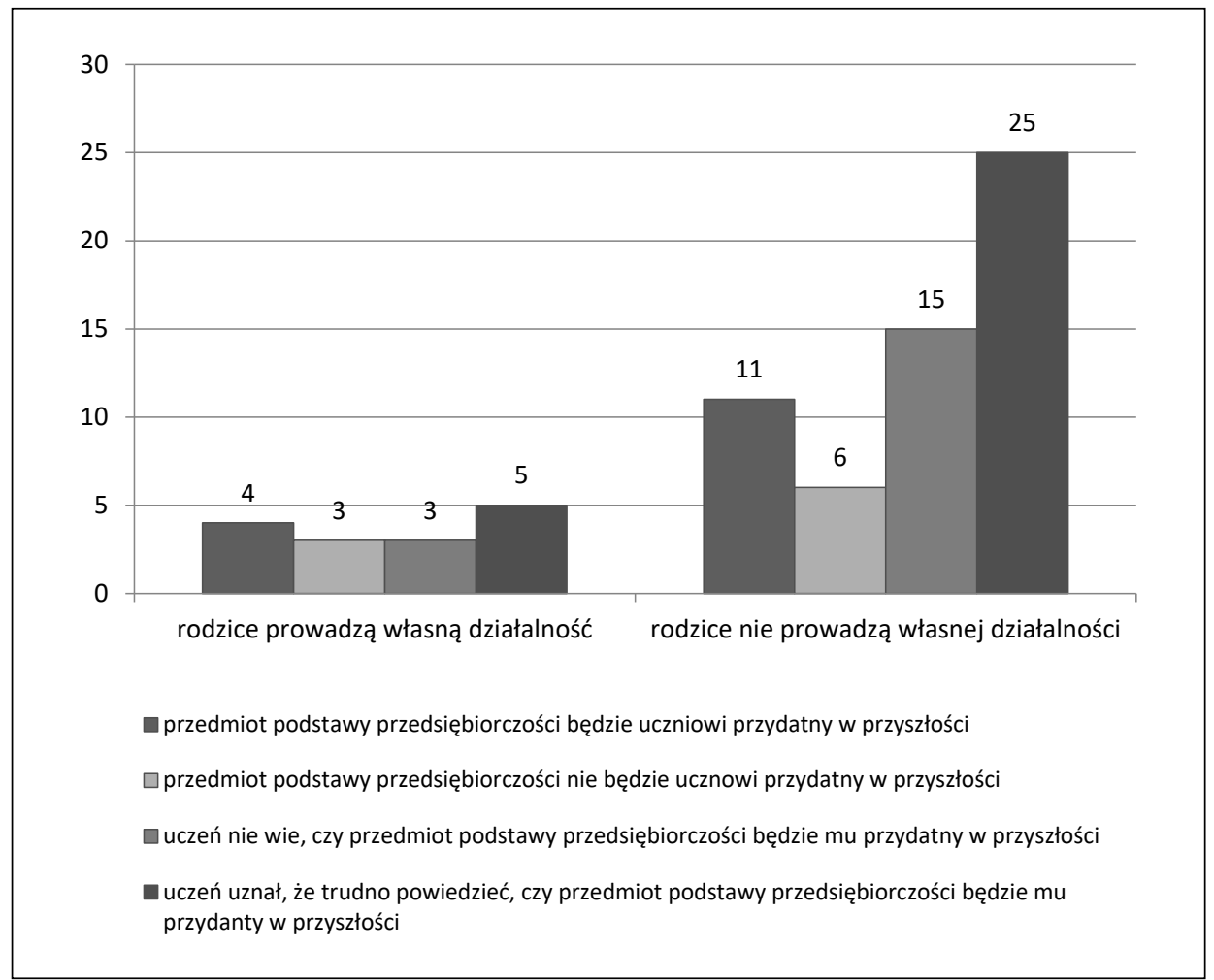

Źródło: opracowanie własne na podstawie badań własnych 
Na podstawie ryciny 5 trudno stwierdzić zależność między opinią dotyczącą przydatności przedmiotu w przyszłości a prowadzeniem działalności przez rodziców ucznia. Zauważyć można jedynie, że uczniowie, których rodzice nie prowadzą działalności, zdecydowanie częściej odpowiadali, że trudno im stwierdzić, czy przedmiot będzie przydatny w przyszłości. Można przypuszczać, że nie zastanawiają się oni nad mechanizmami działającymi na rynku oraz zagadnieniami związanymi z postawami przedsiębiorczymi. Może to być jedynie przypuszczenie, ponieważ ich odpowiedź może być podyktowana tym, że jeszcze nie zastanawiali się nad swoją przyszłością.

Wśród zagadnień wymienionych w podstawie programowej dotyczących przedmiotu podstawy przedsiębiorczości w opinii uczniów najczęściej poruszanymi zagadnieniami na zajęciach były: rodzaje rynków ( 63 wskazania), podmioty gospodarki rynkowej (56 wskazań), mechanizmy rynkowe (56 wskazań), struktury rynkowe (57 wskazań), popyt i podaż na rynku pracy ( 55 wskazań). Najrzadziej poruszanymi tematami były umowy bankowe i ubezpieczenia (39 wskazań) oraz symulowana rozmowa kwalifikacyjna (36 wskazań).

Według respondentów interesującymi zagadnieniami są: pieniądz i jego obieg (27 wskazań) oraz: pisanie dokumentów aplikacyjnych (np. CV), symulowana rozmowa kwalifikacyjna, prawa i obowiązki pracownika i pracodawcy (po 26 wskazań).

Respondenci określić mieli, które zagadnienia są dla nich najbardziej i najmniej interesujące. Potwierdziły się wcześniejsze odpowiedzi dotyczące zainteresowania ucznia poszczególnymi zagadnieniami. Uczniowie określili, że najbardziej interesuje ich zagadnienie pieniądza i jego obiegu (15 wskazań) oraz symulowana rozmowa kwalifikacyjna (14 wskazań). Najmniej interesującym zagadnieniem według respondentów są fazy cyklu koniunkturalnego (17 wskazań).

\section{Podsumowanie}

Na podstawie wyników badań, będących wyłącznie badaniami rozpoznawczymi, których nie można odnosić do populacji, można zauważyć m.in., że przedmiot podstawy przedsiębiorczości jest raczej uważany przez uczniów za przydatny. Zdecydowana większość respondentów uważa, że liczba godzin w ramach przedmiotu podstawy przedsiębiorczości jest wystarczająca. W ramach zajęć, według części uczniów, odbywały się ciekawe wydarzenia, które uatrakcyjniały lekcje. Zauważyć należy jednak, że nie były one wskazywane przez wszystkich uczniów, tak więc nie każdy nauczyciel ma chęć lub czas podejmowania wysiłku do zorganizowania takich atrakcji. Uczniowie nie potrafili jednoznacznie stwierdzić, czy przedmiot przygotował ich do działań przedsiębiorczych w przyszłości. Wyrazili oni jedynie przypuszczenie, że przedmiot raczej ich do nich przygotował.

Można zauważyć, że wśród zagadnień szczególnie interesujących młodych ludzi są te związane $\mathrm{z}$ ich przyszłością, jak np. symulowana rozmowa kwalifikacyjna czy pieniądz i jego obieg w gospodarce. Z pewnością warto skupić się, w miarę możliwości czasu lekcyjnego, na pogłębianiu tematów, które interesują uczniów. Być może to właśnie poruszanie takich kwestii bardziej zachęci ich do przedmiotu.

Autorka po przeprowadzeniu ankiety zauważyła, że planując dalszy kierunek badań, kwestie, o które warto zapytać respondentów w przyszłości, to m.in.: planowany tryb studiów i planowany wymiar czasu pracy. Należy też spróbować określić, czy uczeń zastanawiał się nad tym, jak pokierować swoimi działaniami w przyszłości. Zdecydowanie badania należy przeprowadzić na większej grupie uczniów, być może dzieląc ich na osoby, 
których rodzice prowadzą własną działalność gospodarczą, i na osoby, których rodzice nie prowadzą własnej działalności. Interesujące mogłoby się okazać spojrzenie na przedsiębiorczość z perspektywy tych dwóch grup.

W celu zgłębienia problemu należałoby uwzględnić poziom szkół oferujących nauczanie z zakresu przedsiębiorczości, ich rozmieszczenie terytorialne, a po stronie respondentów - czynniki kulturowe, osobowościowe i socjalizacyjne mające wpływ na ich poglądy w zakresie nauczania przedsiębiorczości. Tym samym, dalsze kierunki badań wymagałyby poszerzenia problematyki badania poglądów o dodatkowe zmienne zależne i niezależne, co umożliwiałoby rozpoznanie kluczowych czynników mogących mieć wpływ na kształtowanie poglądów w zakresie przedsiębiorczości.

Literatura

References

Bigos, K. (2018). Skłonność studentów do podejmowania działalności gospodarczej w zależności od wielkości miasta pochodzenia. Horyzonty Wychowania, 17(43), 61-71.

Cichoń, M., Piotrowska, I. (2012). Kształtowanie kompetencji kluczowych wśród studentów geografii poprzez metodę projektu, esej geograficzny i recenzję. Prace Komisji Edukacji Geograficznej, 2, 151-168.

Ernst-Milerska, R. (2015). Przedsiębiorczość jako przedmiot szkolny: między kształceniem realnym a ogólnym. Studia $z$ Teorii Wychowania, tom 6, 3(12), 193-207.

Głodowska, A. (2018). Gender Differences in Educational Attainment: The Evidence from the European Union Countries. Horyzonty Wychowania, 17(43), 221-230.

Głodowska, A. (2017). Level of Education and Economic Growth in the Member States of the European Union: A Comparative Analysis. Horyzonty Wychowania, 16(37), 105-118.

Hajdukiewicz, A. (2018). Lifelong learning jako warunek ramowy innowacyjności gospodarek państw Unii Europejskiej w świetle metodologii European Innovation Scoreboard. Horyzonty Wychowania, 17(43), 187-196.

Jeszka, A.M. (2013). Problemy badawcze i hipotezy w naukach o zarządzaniu. Organizacja i Kierowanie, 5(158), 31-39.

Kosała, M. (2016). Edukacja przedsiębiorczości - analiza tendencji, metod i narzędzi w zakresie nauczania przedsiębiorczości w środowisku akademickim. Horyzonty Wychowania, 15(34), 49-66.

Kosała, M. (2014). Badanie postaw przedsiębiorczych wśród młodzieży jako fundament kształtowania postawy odpowiadającej wyzwaniom współczesnego świata. Horyzonty Wychowania, 13(28), 317-340.

Kuratko, D.F. (2005). The Emergence of Entrepreneurship Education: Development, Trends and Challenges. Entrepreneurship Theory and Practice, 29(5), 577-597.

Kwaśny, J., Żur, A. (2018). Tutoring a kształtowanie kompetencji przedsiębiorczych - studium przypadku Wydziałowej Indywidualnej Ścieżki Edukacyjnej. Horyzonty Wychowania, 17(43), 85-94.

Łobocki, M. (1984). Metody badań pedagogicznych. Warszawa: Państwowe Wydawnictwo Naukowe.

Maciejewski, M. (2018). Postawy i działania przedsiębiorcze w Polsce i na świecie w świetle oceny kształcenia biznesowego. Horyzonty Wychowania, 17(43), 209-220.

Płaziak, M., Rachwał, T. (2014). Kształcenie w zakresie przedsiębiorczości w polskich uniwersytetach na studiach nieekonomicznych (na przykładzie kierunku geografia). Horyzonty Wychowania, 13(26), 249-266.

Poczmańska, A., Pierwieniecka, R. (2016). Edukacja przedsiębiorczości w ramach kształcenia zawodowego a sytuacja jego absolwentów na rynku pracy. Przedsiębiorczość - Edukacja, 12, 392-403.

Premand, P., Brodmann, S., Almeida, R., Grun, R., Barouni, M. (2016). Entrepreneurship Education and Entry into Self-Employment Among University Graduates. World Development, 77, 311-327.

Sadowska, M. (2016). Edukacja w zakresie przedsiębiorczości w polskim systemie kształcenia oraz w państwach europejskich. Przedsiębiorczość Międzynarodowa, 2(1), 149-164. 
Tracz, M. (2015). Przedmiot podstawy przedsiębiorczości w opinii uczniów i nauczycieli - studium porównawcze. Przedsiębiorczość - Edukacja, 11, 391-400.

Tracz, M., Rachwał, T. (2008). Metody nauczania i środki dydaktyczne stosowane przez nauczycieli podstaw przedsiębiorczości - wyniki badań. Przedsiębiorczość - Edukacja, 4, 325-330.

Tracz, M., Rachwał, T. (2007). Przedmiot podstawy przedsiębiorczości - założenia realizacji a przygotowanie nauczycieli. Przedsiębiorczość - Edukacja, 3, 286-296.

Urbaniec, M. (2016). Rola uniwersytetu w kształtowaniu kompetencji przedsiębiorczych zgodnie z koncepcją zrównoważonego rozwoju. Horyzonty Wychowania, 15(35), 73-92.

Wach, K. (2014). Edukacja dla przedsiębiorczości: pomiędzy przedsiębiorczą pedagogiką a edukacją ekonomiczną i biznesową. Horyzonty Wychowania, 13(28), 11-32.

Wach, K. (2013). Edukacja na rzecz przedsiębiorczości wobec współczesnych wyzwań cywilizacyjno-gospodarczych. Przedsiębiorczość - Edukacja, 9, 246-257.

Wąsik, H. (2010). Nauczanie przedsiębiorczości w kontekście integracji europejskiej. Przedsiębiorczość - Edukacja, 6, 486-492.

Wilson, F., Kickul, J., Marlino, D. (2007). Gender, Entrepreneurial Self-Efficacy, and Entrepreneurial Career Intentions: Implications for Entrepreneurship Education. Entrepreneurship Theory and Practice, 31(3), 387-406.

Zioło, Z. (2012). Miejsce przedsiębiorczości w edukacji. Przedsiębiorczość - Edukacja, 8, 10-23.

Ziółkowska-Weiss, K. (2016). Ocena nauczania podstaw przedsiębiorczości przez uczniów liceum ogólnokształcącego. Przedsiębiorczość - Edukacja, 12, 457-470.

Anna Dudoń, magister, doktorantka w dyscyplinie ekonomia i finanse na Uniwersytecie Rolniczym im. Hugona Kołłątaja w Krakowie, Wydział Rolniczo-Ekonomiczny, Katedra Statystyki i Polityki Społecznej. Jej zainteresowania badawcze dotyczą obszarów związanych z ekonomią społeczną i mikroekonomią. Szczególnie interesuje się sytuacją gospodarstw agroturystycznych w Polsce południowo-wschodniej oraz potrzebami społeczeństwa związanymi ze zmianami demograficznymi, takimi jak wzrost liczby ludności w wieku poprodukcyjnym.

Anna Dudoń, MA, PhD student of Economics and Finance at the University of Agriculture in Krakow, Faculty of Agriculture and Economics, Department of Statistics and Social Policy. Research interests concern areas related to social economy and microeconomics. She is particularly interested in the situation of agritourism farms in South-Eastern Poland and with the needs of society related to demographic changes, such as the increase in the post-working age population.

ORCID: 0000-0002-0979-0614

\section{Adres/Address:}

Uniwersytet Rolniczy in. Hugona Kołłątaja w Krakowie

Wydział Rolniczo-Ekonomiczny

Katedra Statystyki i Polityki Społecznej

Al. Mickiewicza 21

31-120 Kraków, Polska

e-mail: annadudon@onet.pl 